\title{
The Appearance of Broiler That Given Golden Apple Snail Meat (Pomacea canaliculata) Flour as Replacement of Fish Flour
}

\author{
Gordianus Jawa, Ni Ketut Etty Suwitari*, I Gusti Agus Maha Putra Sanjaya \\ Faculty of Agriculture, Warmadewa University, Indonesia \\ * Corresponding author: suwitary62@yahoo.co.id
}

\begin{abstract}
The purpose of this study was to determine the effect of giving golden snail meat flour in broiler rations aged 2-5 weeks to the appearance of broiler chickens and to find out what level of golden snail meat flour can give the results of body weight gain, final body weight, feed consumption, and conversion best ration. This study used a Completely Randomized Design with 5 treatments and 3 replications for each treatment. The five treatments were rations without the content of golden snail meat flour as control and rations containing golden snail meat flour 5\%, 10\%, 15\%, and 20\%. The parameters observed were bodyweight gain, final body weight, feed consumption, and FCR (Feed Conversion Ratio). The data obtained were analyzed by analysis of variance. If between treatments showed a real difference, then proceed with Duncan's test. The results of the study of the addition of golden snail meat flour (Pomacea canaliculata) in broiler chicken rations had a very significant effect $(P<0.01)$ on the research variables' weight gain, final body weight, and lower FCR. Whereas the consumption of rations had a significant effect $(P<0.05)$. In treatment $R 2(10 \%)$ gave better results than other treatments $(R 0, R 1, R 3$, and $R 4)$. This means that the treatment of giving golden snail meat flour in the ration apparently can increase the weight gain of broiler chickens. This is because the golden snail contains quite high protein. From the results of this study, it can be concluded that the administration of golden snail meat flour (Pomacea canaliculata) in broiler rations has a very significant effect on increasing weight gain, final weight, and decreasing FCR and significantly influencing ration consumption.
\end{abstract}

Keywords: Broiler chicken, appearance, golden snail meat flour (Pomecea canaliculata).

\section{Introduction}

Increased welfare and the level of public awareness of the fulfillment of nutrition, especially animal protein also helped increase the demand for livestock products. Meat is widely used by the community because it has a good taste and high nutrient content. One of the most widely used sources of meat by the people of Indonesia is chicken. So that broilers can achieve optimal productivity, the provision of the right ration, both in quality and quantity must be met. In making rations, fish meal is one of the sources of protein in broiler chicken rations and almost all dietary formulas use the fish meal as a source of protein, but the current fish meal is quite expensive. This is an obstacle for farmers so that to reduce costs can be replaced with local ingredients that are cheaper, easier to obtain, have good nutritional content, and do not compete with human needs. One of them is snail mas (Pomacea canaliculata) because the nutritional content of golden snails is almost like a fish meal. The nutritional composition of golden snail flour is as follows, Crude protein (PK) 46.2 \%, Metabolic energy (ME) $1920 \mathrm{Kkal} / \mathrm{kg}$, Calcium (Ca) 2.9\%, dan Phosphor (P) $0.35 \%$ [1]. Based on the above, the researcher is interested in researching with the title Appearance of Broiler that Given Golden Apple Snail Meat (Pomacea canaliculate) Flour as Replacement of Fish Flour, in broiler rations. This research was conducted to determine the effect of giving golden snail meat flour (Pomacea canaliculata) in the amount of 5\%,10\%, 15\%,20\%, in the ration on the appearance of a broiler. The purpose of this study was to determine the effect of giving golden snail 
meat flour in age broiler rations 2-5 weeks on appearance and to find out what level of golden snail meat flour can give the best bodyweight gain, final body weight, feed consumption and feed conversion.

\section{Material and Methods}

\subsection{Place and Time of Research}

This research was conducted at Banjar Kebon Kori Klod, Kesiman Village, East Denpasar District, Denpasar City, this research was carried out for 5 weeks from 9 February to 17 March 2019.

\subsection{Research Materials}

The chicken used in this research is broiler CP 707 that bought at PT. Tohpati Poultry Shop located in WR. Supratman, 281. There were 60 chickens used in this study with homogeneous bodyweight, with an average weight of $531 \pm 5 \%$.

The tool used in this study was zinc for drying golden snail meat, mortar to pound dried snail meat, Joilbrand digital scales with a capacity of $3 \mathrm{~kg}$, sensitivity $0.1 \mathrm{~g}$, and hanging capacity Portable scales of $5,000 \mathrm{~g}$, with sensitivity $0.01 \mathrm{~g}$, plastic to store the treatment ration, tub to mix the ration, plastic cup to measure oil.

\subsection{Research Design}

This research uses a completely randomized design (CRD) with 5 treatments and 3 replications. Each test contains 4 chickens aged 2 weeks with a homogeneous weight. The treatments are as follows: R0: Rations containing gold snail meat flour 0\% (feed control), R1: Rations containing gold snail meat flour 5\%, R2: Rations containing gold snail meat flour 10\%, R3: Rations containing gold snail meat flour $15 \%$, R4: Rations containing gold snail meat flour $20 \%$.

\subsection{Research Variable}

The variables observed in this study were: Initial body weight is the weight of the chicken at the age of 2 weeks, weight gain is the final chicken weight minus the initial body weight, Final body weight is the weight obtained at the end of the study which is 5 weeks old, ration consumption is obtained by reducing the amount of ration given with the rest of the ration every week, FCR (Feed Conversion Ratio) is the ratio between the amount of ration consumed with weight gain.

\section{Results and Discussion}

Adding golden snail meat flour (Pomacea canaliculata) in broiler chicken rations have a very real effect $(\mathrm{P}<0.01)$ on the weight gain research variable, final weight, and lowering FCR. Whereas the consumption of rations had a significant effect $(\mathrm{P}<0.05)$. On treatment R2 (10\%) give better results than other treatments (R0, R1, R3, dan R4).

From the results of this study the highest weight gain was obtained in the treatment $\mathrm{R} 2$ $(10 \%)$ in the amount of $834.26 \mathrm{~g}$, and lowest in ration treatment without golden snail meat flour (R0) in the amount of $601.51 \mathrm{~g}$. This means that the treatment of giving golden snail meat flour in the ration apparently can increase the weight gain of broiler chickens. This is because the golden snail contains quite high protein. 
Table 1

The appearance of broiler that given golden apple snail meat flour as replacement of fish flour

\begin{tabular}{lllllll}
\hline \multirow{2}{*}{ Variable } & \multicolumn{2}{l}{ Treatment } & & & \\
\cline { 2 - 7 } & R0 & R1 & R2 & R3 & R4 & SEM $^{2)}$ \\
\hline Initial Bodyweight (g) & $528.66^{\mathrm{a}}$ & $532.70^{\mathrm{a}}$ & $532.19^{\mathrm{a}}$ & $528.87^{\mathrm{a}}$ & $527.49^{\mathrm{a}}$ & 1.63 \\
Weight gain (g) & $601.51^{\mathrm{b}}$ & $735.78^{\mathrm{ab}}$ & $834.26^{\mathrm{a}}$ & $799.22^{\mathrm{a}}$ & $797.14^{\mathrm{a}}$ & 18.62 \\
Final Weight (g) & $1130.17^{\mathrm{b}}$ & $1268.48^{\mathrm{ab}}$ & $1366.46^{\mathrm{a}}$ & $1328.09^{\mathrm{a}}$ & $1324.63^{\mathrm{a}}$ & 19.30 \\
Ration consumption & $1605.64^{\mathrm{bc}}$ & $1838.65^{\mathrm{a}}$ & $1755.54^{\mathrm{ab}}$ & $1491.58^{\mathrm{c}}$ & $1519.95^{\mathrm{c}}$ & 36.24 \\
FCR & $2.67^{\mathrm{a}}$ & $2.50^{\mathrm{a}}$ & $2.11^{\mathrm{b}}$ & $1.87^{\mathrm{c}}$ & $1.91^{\mathrm{bc}}$ & 0.03 \\
\hline
\end{tabular}

Information :

1. Values with different letters in the same line show real differences $(\mathrm{P}<0.05)$ until very real $(\mathrm{P}<0.01)$.

2. SEM: Standard Error of The Treatment Means

This research is supported by opinions from [2] which states that golden snail is a potential source of feed protein because the protein content is equal to fish meal. Giving as much gold snail meat flour $10 \%$ in duck ration can increase the rate of growth and production of duck eggs up to $80 \%$ and able to balance the use of fish flour [3].

Factors that influence weight gain include ration consumption, environment temperature, and chicken strain. Weight loss is also influenced by the ration given, a good ration must have quality and quantity, and must contain proteins and amino acids that are suitable to the needs of livestock [4].

The highest broiler chicken weight gain was obtained at R2 treatment (10\%) and lowest on the R0 treatment (control). This means that by giving golden snail meat flour it can increase the final body weight of broiler chickens. Final body weight is influenced by the growth of broiler chickens. The factors that influence the growth of broiler chickens are as follows: ration (feed) consumed, DOC seed, ambient temperature, and maintenance [4]. Feed consumption is a very influential factor in the growth of broiler chickens and consumption is influenced by temperature, feeding system, chicken health, feed quality, and genetic characteristics of broiler chickens [5].

The highest consumption of ration in this study was obtained in the treatment R1 (5\%) and then there's a decreasing number on ration consumption in R2 (10\%), R3 (15\%), and R4 (20\%) treatment. This is presumably because the energy content in the ration containing golden snail meat flour is higher according to the results of laboratory analysis, so the higher the level of golden snail meat flour, the higher the energy content in the ration, which can cause the consumption of rations to decrease because the chicken will consume less ration when the energy is fulfilled. This is according to the opinion of [6] which states that basically, livestock uses food to meet the energy needs that will be used in the body's physiological functions and launching synthetic reactions on the body, livestock, or chickens eat to meet their energy needs. When the energy needs are met, the chicken will stop eating or in other words, the limiting consumption of rations in poultry is energy. Increasing the metabolic energy content of the ration, then the consumption will decrease because the livestock already feels full. The consumption of rations is also influenced by the color of the ration given. The nature of the color stimulates the attention of broiler chickens so that more is consumed. The level of ration consumption is influenced by several factors including sex, age, livestock nation, and the quality of feed nutrients, especially energy, and crude protein [7]. 
FCR (Feed Conversion Ratio) is a benchmark to assess the high and low efficiency of ration use by broilers. The lower the FCR value, the better the efficiency of ration use. FCR is the ratio between ration consumption and bodyweight gain. Adding golden snail meat flour 15\% (R3) in broiler chicken rations tend to give the best results on feed conversion with an average of 1.87. This is because the consumption of rations in treatment R3 is lower than other treatments so that it can affect the FCR value (Table 1).

The conversion value of rations is influenced by the consumption of rations to meet weight gain [8]. The smaller conversion value of rations means that the provision of rations is more efficient, but if the feed conversion gets bigger, waste has occurred [9], [10]. FCR can also be influenced by several factors including the following Day Old Chick (DOC) quality, nutritional quality, maintenance management, and quality of the cage [11]. [12] also stated that the factor affecting ration conversion rates was ration quality, chicken strain, and the procedure for giving rations.

\section{Conclusion}

From the results of this study, it can be concluded that: The giving of golden snail meat flour (Pomacea canaliculata) in broiler chicken rations has a very significant effect on increasing weight gain, final body weight, and decreasing FCR (Feed Conversion Ratio) and significantly influencing the consumption of rations, giving golden snail meat flour in rations can increase weight gain and final body weight. For more efficient results, the treatment R3 (15\%).

\section{Acknowledgments}

Thank you to all those who have helped to contribute energy and thought in completing this research.

\section{References}

[1] BPTP Kalimantan Timur (2001). Pengkajian Teknologi Budidaya Ayam Buras. PAATP Kalimantan Timur.

[2] Subhan A, Yuwanta T \& Sidadolog J H P. (2010). Pengaruh Kombinasi Sagu Kukus (Metroxylon Spp) dan Tepung Keong Mas (Pomacea Spp) sebagai Pengganti Jagung Kuning terhadap Penampilan Itik Jantan Alabio, Mojosari dan Hasil Persilangannya (The Effect of Steaming Sago (Metroxylon Spp) and Golden Snail Meal. Buletin Peternakan, 34(1), 30-37.

[3] Sulistiono (2007). Pengelolaan Keong Mas (Pomacea canaliculata). Prosiding Konferensi Sains Kelautan dan Perikanan Indonesia I. Kampus FPIK, Institut Pertanian Bogor, Dermaga, 17-18 juli 2007: 124-136.

[4] Muhamad (2012). Faktor Pendukung Pertumbuhan Ayam Broiler. http://mynameyunus.blogspot.co.id/ 2012/05/faktor-pendukung-ayam.html.[5 Mei 2018]

[5] Rasyaf (2003). Beternak Ayam Pedaging. Penerbit PT Swadaya, Jakarta

[6] Anggorodi R (1995). Kemajuan Mutahir Dalam Ilmu Makanan Ternak Unggas. Penerbit Universitas Indonesia. Jakarta.

[7] Parakasi A. (1999). Ilmu Nutrisis dan Makanan Ternak Ruminansia. UI Press. Jakarta.

[8] Zuidhof M J, Seheider B I, Camey V I, Korver D R \& Robinson F E. (2014). Growth, Eviciency and Yield of Comersial Broilers From 1957, 1978 and 2005. Poult. Sci. 93(12) 2970-2982

[9] Rasyaf M. (1994). Makanan Ayam Broiler. Kanisius, Yogyakarta

[10] Rasyaf M. (2003). Beternak Ayam Pedaging, PT. Penebar Swadaya; Jakarta.

[11] Satyaningtijas A S, Yufiandri R, Wulandari R, Darwin V M \& Santa Nova A S. (2016). Performa dan Kecernaan Pakan Ayam Broiler yang diberi Hormon Testosteron dengan Dosis Bertingkat. Acta VETERINARIA Indonesiana, 3(1), 29-37. 
[12] Sapsuha Y \& Sjafani (2006). Teknologi Tepung Daun Sebagai Industri Pakan Berbasis Sumber Daya Tanaman Lokal di Maluku Utara. Laporan Penelitian Dosen Muda (Belum di publikasikan). Lembaga Penelitian dan Pengabdian Masyarakat (LPPM) Unkhair, Ternate. http://id.wikipedia.org/wki/kelor. Diakses 24 juni 2019. 